\title{
BIOLOGI REPRODUKSI TUNA MATA BESAR (Thunnus obesus) YANG TERTANGKAP DI SAMUDERA HINDIA
}

\author{
Ria Faizah dan Budi Iskandar Prisantoso \\ Peneliti pada Pusat Riset Perikanan Tangkap, Ancol-Jakarta \\ Teregistrasi I tanggal: 24 Juni 2010; Diterima setelah perbaikan tanggal: 20 Juli 2010; \\ Disetujui terbit tanggal: 30 Juli 2010
}

\begin{abstract}
ABSTRAK
Tujuan penelitian ini adalah untuk mendapatkan informasi mengenai aspek reproduksi ikan tuna mata besar (Thunnus obesus) di perairan Samudera Hindia. Sebanyak 42 contoh gonad dari ikan tuna mata besar yang tertangkap perairan Samudera Hindia antara bulan Maret sampai Oktober 2008 digunakan dalam penelitian ini. Pengamatan meliputi struktur morfologi gonad ikan, perkembangan gonad, diameter telur, dan fekunditas. Hasil penelitian ini menunjukan bahwa ikan tuna mata besar yang tertangkap memiliki tingkat kematangan gonad I, II, dan IV. Nilai gonado somatic index rata-rata tuna mata besar semakin meningkat seiring dengan meningkatnya tingkat kematangan gonad. Musim pemijahan untuk tuna mata besar diduga terjadi pada bulan Oktober. Tuna mata besar memiliki fekunditas antara 8.163.715-10.365.317 butir dan memiliki pola pemijahan berganda.
\end{abstract}

\section{KATAKUNCI: biologi reproduksi , tuna mata besar, Samudera Hindia}

ABSTRACT: $\quad$ Reproductive biology of bigeye tuna (Thunnus obesus) caught in the Indian Ocean. By: Ria Faizah and Budi Iskandar Prisantoso

The objective of this research is to study the reproductive biology of big eye tuna (Thunnus obesus) from Indian Ocean. A numbers of 42 gonad samples were taken from fresh individuals captured in the Indian Ocean during period of March until October 2008. The observation comprised of morphological structure of gonad, gonad development, oocytes diameter, and batch fecundity. The results showed that the gonad maturity stages of big eye tuna were ranged from immature (the gonad maturity stage of I and II) to mature (the gonad maturity stage of IV), and the gonado somatic index value increase along with increase of gonad maturity. Spawning season for big eye tuna estimated was in October, range of fecundity were 8.163.715-10.365.317 oocytes, and the spawning type was partial spawned.

\section{KEYWORDS: $\quad$ reproductive biology, bigeye tuna, Indian Ocean}

\section{PENDAHULUAN}

Bigeye tuna atau tuna mata besar (Thunnus obesus Lowe, 1839) adalah spesies pelagis oseanik yang hidup di perairan tropis sampai subtropis, memiliki distribusi vertikal dengan kisaran luas sampai mencapai kedalaman sampai $600 \mathrm{~m}$ dan tersebar di perairan Samudera Atlantik, Hindia, dan Pasifik (Collette \& Nauen, 1983). Bigeye tuna memiliki nilai komersial yang tinggi. Menurut Uktolseja et al. (1997) Indonesia merupakan salah satu negara perikanan tuna yang penting di Samudera Hindia yang memiliki potensi di wilayah Zona Ekonomi Ekslusive Indonesia pada batas 216.275 ton/tahun atau 39,4\% dari total potensi tuna Indonesia yaitu 548.387 ton/tahun. Komisi Tuna Samudera Hindia (Indian Ocean Tuna Commission) memperkirakan hasil tangkapan tuna dan sejenisnya (tuna like species) dari Indonesia di Samudera Hindia 177.384 ton pada tahun 2000 (Herrera, 2002, dalam Proctor et al., 2003). Hasil tangkapan tuna mata besar yang didaratkan di Benoa pada tahun 2002 diperkirakan mencapai 11.646 ton atau $43,5 \%$ dari total hasil tangkapan tuna yaitu 26.747 ton (Proctor et al., 2003).

Pemanfaatan dan permintaan pasar dari ikan tuna mata besar semakin meningkat dari tahun ke tahun. Hal ini terindikasi dengan semakin bertambahnya jumlah armada yang beroperasi di wilayah perairan tersebut. Direktorat Jenderal Perikanan Tangkap (2005) mencatat bahwa ada sekitar 6.547 unit kapal tuna longline di Indonesia pada tahun 2003. Jumlah tersebut meningkat dibandingkan pada tahun 2002 yang hanya berjumlah 2.264 unit. Diduga jumlah kapal tuna longline yang beroperasi di seluruh perairan Indonesia sekitar 1.400 unit, di mana kira-kira 1.200 beroperasi di Samudera Hindia (Pusat Riset Perikanan Tangkap, 2002). Seiring dengan adanya peningkatan ini dikhawatirkan pada masa mendatang populasi sumber daya ikan tuna mata besar akan semakin menurun.

Penelitian tentang biologi reproduksi ikan tuna pernah dilakukan oleh Davis et al. (1996) khususnya 
reproduksi tuna sirip biru (Thunnus macoyii) di perairan selatan Jawa dan Bali dengan berbasis pendaratan di Benoa. Sementara itu untuk jenis ikan tuna mata besar jarang dilakukan khususnya di perairan Samudera Hindia wilayah perairan Indonesia. Nootmorn (2004) pernah melakukan pengamatan terhadap biologi reproduksi ikan tuna mata besar di perairan Samudera Hindia dengan basis pendaratan di Phuket Thailand, Figueiredo et al. (2008) melakukan penelitian biologi reproduksi ikan tuna mata besar di perairan Samudera Atlantik bagian barat. Mengingat penelitian aspek biologi reproduksi ikan tuna mata besar di Samudera Hindia wilayah perairan Indonesia terbatas maka penelitian ini menjadi penting.

Penelitian ini bertujuan untuk mendapatkan informasi mengenai aspek biologi reproduksi ikan tuna mata besar, Thunnus obesus hasil tangkapan tuna longline yang di daratkan di Benoa, Bali.

\section{BAHAN DAN METODE}

\section{Lokasi dan Waktu Penelitian}

Penelitian ini dilakukan di perairan Samudera Hindia pada bulan Maret sampai Oktober 2008. Pengambilan contoh gonad ikan tuna mata besar dilakukan dengan mengikuti aktivitas penangkapan kapal tuna longline yang berbasis di Benoa. Lokasi daerah penangkapan ikan terdapat di perairan Samudera Hindia sebelah selatan Jawa Timur, Bali sampai ke Nusa Tenggara pada kisaran koordinat $09^{\circ} 11^{\prime}-16^{\circ} 07^{\prime}$ LS dan 110¹5'-118³5' BT (Gambar 1).

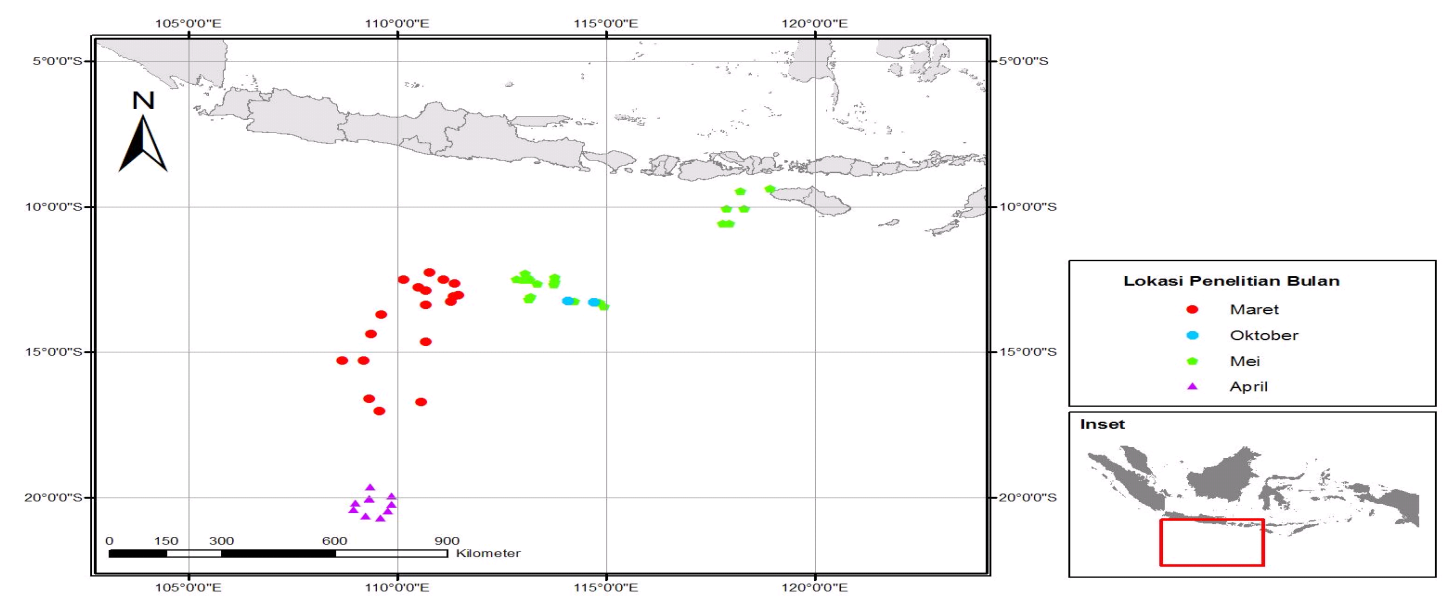

Gambar 1. Peta lokasi pengambilan contoh ika tuna mata besar.

Figure 1. Map of sampling positions for big eye tuna.

\section{Pengambilan Contoh Gonad}

Untuk memperoleh contoh gonad dan mengetahui jenis kelaminnya maka dilakukan pembedahan ikan dengan menggunakan disecting set. Setelah diperoleh contoh gonad, maka dilakukan pengamatan sebagai berikut:

1. Penentuan tingkat kematangan gonad secara makroskopis yang mengacu pada Schaefer \& Orange (1956).

2. Penimbangan bobot gonad total.

3. Penimbangan contoh gonad $\pm 5 \mathrm{~g}$ untuk keperluan analisis histologi yang kemudian diawetkan dalam larutan formalin 10\%. Pengambilan contoh gonad dilakukan pada bagian arterior, median, dan posterior.

4. Penimbangan bobot gonad betina untuk pengukuran diameter telur dan fekunditas seberat $\pm 5 \%$ dari bobot total gonad yang diawetkan dalam larutan gilson.
Untuk mempelajari tingkat kematangan gonad dilakukan pengamatan secara anatomis dan histologis.

\section{Pengamatan secara morfologis}

Pengamatan tingkat kematangan gonad secara morfologis dilakukan secara langsung di lapangan dengan memperhatikan ciri-ciri dari tiap tingkat kematangan gonad jantan dan betina. Menurut Effendie (1997) dasar yang digunakan untuk menentukan tingkat kematangan gonad secara morfologi adalah bentuk, ukuran panjang, dan bobot gonad yang berhubungan dengan ukuran ikan, warna, dan pengisian ovarium dalam rongga tubuh. Dalam penelitian ini penentuan tingkat kematangan gonad mengikuti kriteria berdasarkan atas Schaefer \& Orange (1956) (Tabel 1) 
Tabel 1.

Kriteria tingkat kematangan gonad menurut Schaefer \& Orange (1956)

Table 1.

The gonad maturity stage criteria based on Schaefer \& Orange (1956)

\begin{tabular}{cl}
\hline $\begin{array}{c}\text { Tingkat kematangan gonad } \\
\text { (ovary)/The gonad maturity stage }\end{array}$ & \multicolumn{1}{c}{ Deskripsi/Description } \\
\hline I. Dara Berkembang (Immature) & $\begin{array}{l}\text { Gonad memanjang dan ramping, jenis kelamin dapat ditentukan } \\
\text { dengan kaca pembesar. Ovari jernih berwarna abu-abu sampai } \\
\text { kemerah-merahan, telur satu per satu dapat dilihat dengan kaca } \\
\text { pembesar. }\end{array}$ \\
II. Perkembangan I (Early maturing) & $\begin{array}{l}\text { Ovary membesar, berwarna kemerah-merahan dengan pembuluh } \\
\text { kapiler, bulatan telur belum dapat terlihat dengan mata telanjang, ovari } \\
\text { mengisi sekitar setengah ruang bawah. }\end{array}$ \\
III. Perkembangan II (Late & $\begin{array}{l}\text { Ovary membesar dan membengkak, berwarna orange kemerah- } \\
\text { merahan, butiran telur sudah dapat terlihat dengan mata biasa, ovari }\end{array}$ \\
maturing) & $\begin{array}{l}\text { mengisi 2/3 ruang bawah. } \\
\text { Ovary sangat membesar, butiran telur membesar dan berwarna jernih, } \\
\text { dapat keluar dari lumen dengan sedikit penekanan pada bagian perut, } \\
\text { gonad mengisi penuh ruang bawah. }\end{array}$ \\
IV. Matang (Ripe) & $\begin{array}{l}\text { Termasuk yang memijah sekarang (salin) dan mijah sebelumnya (post } \\
\text { spawning), ovari sangat besar dan lunak (karena mijah). Telur matang } \\
\text { yang tertinggal dalam keadaan terserap, telur berwarna jernih, dan } \\
\text { ada yang tertinggal dalam ovari. Telur akan keluar dengan sedikit } \\
\text { penekanan pada perut. }\end{array}$ \\
\hline
\end{tabular}

\section{Pengamatan secara histologis}

Tingkat kematangan gonad betina dapat juga ditentukan dengan mengamati perkembangan dan kondisi oosit melalui preparat histologis. Analisis preparat histologi mengacu pada Figueiredo et al. (2008) yang membagi tingkat kematangan gonad menjadi empat tingkat yaitu:

a. Belum matang: gonad belum terisi penuh oleh oogonia dan oosit pada tahap perinukleolar.

b. Perkembangan awal: gonad sudah terisi oleh oosit pada tahap vitellogenesis awal. Oogonia dan oosit perinukleolar juga ada.

c. Perkembangan akhir: gonad sudah terisi oosit yang sudah mencapai vitellogeneis akhir dan tahap migrasi. Sudah banyak terdapat butir lemak dan kuning telur.

d. Memijah: gonad penuh dengan kuning telur (fully yolked oocytes) dan segera akan memijah.

\section{Analisis Data}

1. Tingkat kematangan gonad dianalisis dengan indeks kematangan gonad menurut (Effendie 1997):

$$
\begin{aligned}
& \mathrm{GSI}=\frac{\mathrm{Wg}}{\mathrm{W}} \times 100 \% \\
& \text { GSI = gonado somatic index } \\
& \mathrm{Wg} \quad=\text { bobot gonad }(\mathrm{g}) \\
& \mathrm{W} \quad=\text { bobot tubuh ikan tanpa isi perut }(\mathrm{g})
\end{aligned}
$$

2. Penentuan diameter dan pola sebaran telur. Contoh telur diukur pada bagian anterior, tengah, dan posterior dengan menggunakan mikroskop binokuler yang dilengkapi dengan mikrometer pembesaran 10x4 kali. Pola sebaran diameter ukuran telur dianalisis secara deskriptif dengan melihat modus penyebaran ukuran. Apabila terlihat dua modus penyebaran, maka pola pemijahannya sebagian-sebagian (multiple spawning). Jika terdapat penyebaran ukuran satu modus maka pemijahan berlangsung dalam waktu yang singkat dan telur dikeluarkan secara total (total spawning) (Effendie, 2002).

3. Fekunditas. Metode yang digunakan untuk penghitungan fekunditas adalah metode gravimetrik. Tiap contoh diambil $1 \mathrm{~g}$ dan dihitung fekunditasnya dengan menggunakan mikroskop stereo dengan perbesaran $10 \times 10$ dengan rumus (Effendie, 2002):

$$
F=\left[\frac{G}{Q}\right] * N
$$

$$
\begin{array}{rll}
\text { di mana: } & \\
F= & \text { fekunditas } \\
N= & \text { jumlah telur pada gonad contoh } \\
\mathrm{G} & = & \text { bobot total gonad }(\mathrm{g}) \\
\mathrm{Q} & = & \text { bobot gonad contoh }(\mathrm{g})
\end{array}
$$




\section{HASIL DAN BAHASAN}

\section{Perkembangan Gonad}

Hasil pengamatan secara histologis menunjukan bahwa terjadi perubahan tingkat kematangan gonad. Pada tingkat kematangan gonad I ovarium belum matang, didominansi oleh oogonium berdiameter 41,72-73,78 $\mu \mathrm{m}$, sitoplasma lebih tebal dan berwarna ungu dan inti sel berbentuk bulat atau oval. Untuk tingkat kematangan gonad III ukuran diameter oosit meningkat dengan kisaran ukuran 75-200 $\mu \mathrm{m}$, inti kelihatan bertambah besar, jumlah dan ukuran kuning



(a) telur semakin bertambah, sejumlah butiran minyak juga mulai terlihat di dalam sitoplasma, dan oosit mulai berkembang untuk mencapai fully yolked oocytes. Sementara itu untuk tingkat kematangan gonad IV butir kuning telur sudah banyak yang mencapai fully yolked oocytes, diameter telur 220$830,44 \mu \mathrm{m}$, butiran minyak semakin banyak menyebar dari sekitar inti sampai tepi. Oosit dalam tahap nukleus migrasi (inti sel bergerak menuju mikrofil) atau kondisi hidrasi. Pada tingkat ini terlihat bahwa ukuran oosit bervariasi dan tidak ada yang dominan. Hasil pengamatan preparat histologis dapat dilihat pada Gambar 2.

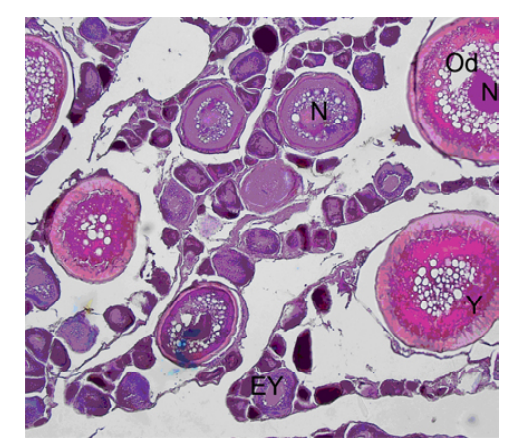

(b)

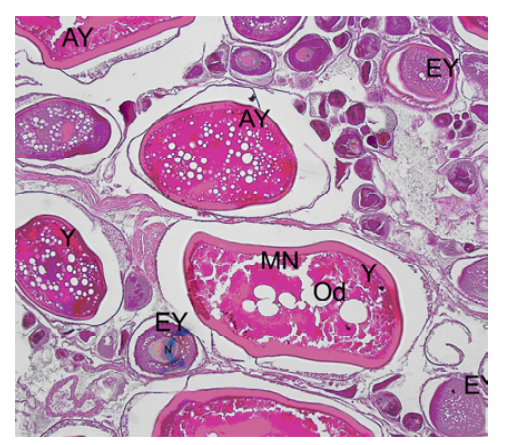

(c)

Gambar 2. Figure 2.
Struktur anatomis dan histologis gonad ikan tuna mata besar (HE, bar $=100 \mu \mathrm{m})$. Anatomic and histologic structure of the gonad of bigeye tuna (HE, bar=100 $\mu \mathrm{m}$ ). Keterangan/Remarks: $\mathrm{EY}=$ early Yolk; $\mathrm{AY}=$ Advance Yolk; Od = Oil droplet

Berdasarkan atas pengamatan struktur histologis tersebut diduga ikan tuna mata besar melakukan pemijahan secara bertahap (partial spawning) di mana telur dengan oosit yang masuk pada tingkat kematangan gonad IV akan dikeluarkan (mijah), dan oosit tingkat kematangan gonad III terus berkembang sampai mencapai tingkat matang (mature) setelah itu telur akan dikeluarkan. Demikian seterusnya sampai ovum mencapai jumlah minimal atau habis. Pola sebaran komposisi oosit yang tidak homogen juga ditemukan pada jenis ikan tuna lainnya, yaitu ikan madidihang (Thunnus albacares) di perairan Hawaii dan Samudera Pasifik bagian barat (Itano, 2000). Perubahan tingkat kematangan gonad setiap bulannya disajikan pada Gambar 3. 


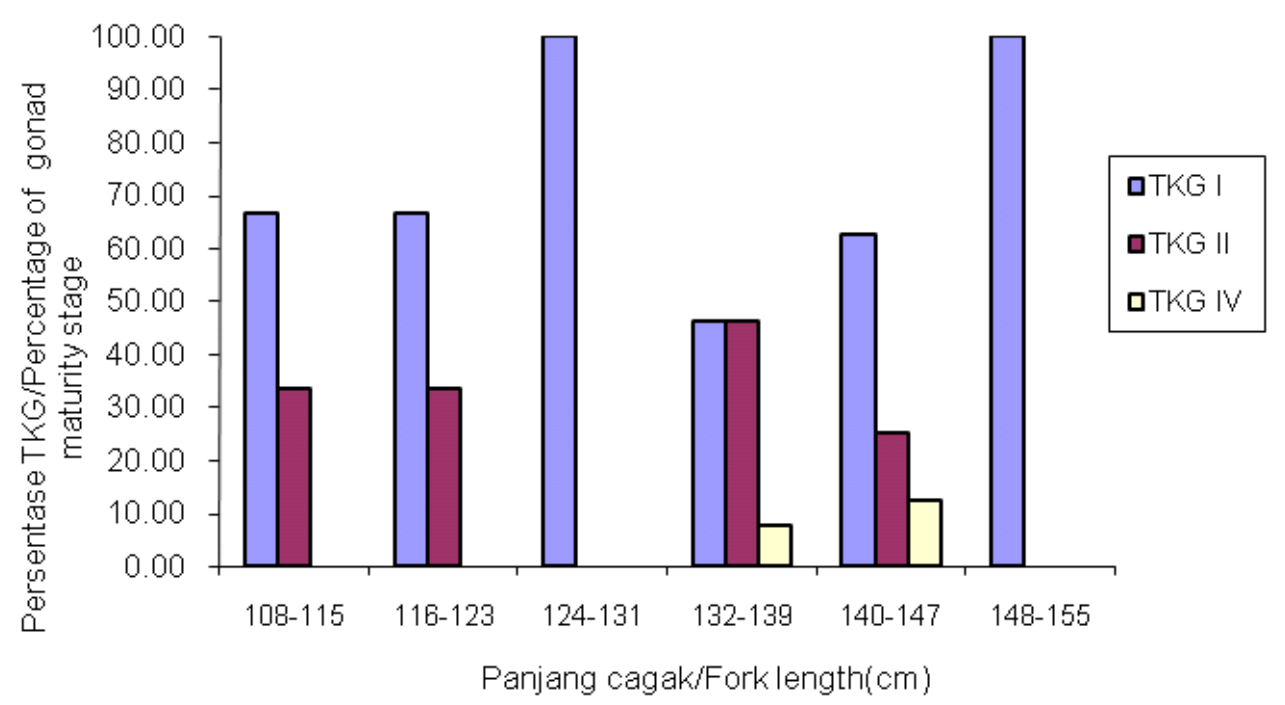

Gambar 3. Hasil pengamatan tingkat kematangan gonad ikan tuna mata besar yang tertangkap dari perairan Samudera Hindia, bulan Maret sampai Oktober 2008.

Figure 3. Gonad maturity stages of bigeye tuna caught in Indian Ocean during March until October 2008.

Berdasarkan atas Gambar 2 terlihat bahwa pada bulan Maret ikan dengan tingkat kematangan gonad I sebanyak 25\%, bulan April 40\%, dan bulan Mei mencapai $100 \%$. Ikan dengan tingkat kematangan gonad II hanya ditemukan pada bulan Maret $75 \%$ dan pada bulan April 60\%. Sementara itu ikan dengan tingkat kematangan gonad IV hanya ditemukan pada bulan Oktober. Hal ini diduga pada bulan Oktober ikan tuna mata besar sudah siap untuk memijah.

\section{Indeks Kematangan Gonad}

Nilai indeks kematangan gonad dapat digunakan untuk menentukan terjadinya musim pemijahan pada ikan. Menurut Effendie (1997), indeks kematangan gonad akan semakin meningkat dan akan mencapai batas maksimum pada saat akan terjadi pemijahan.

Nilai indeks kematangan gonad ikan tuna mata besar terlihat bahwa semakin tinggi tingkat kematangan gonad ikan, maka nilai indeks kematangan gonad semakin meningkat (Gambar 4). Pada grafik tersebut terlihat nilai rata-rata indeks kematangan gonad semakin meningkat seiring dengan semakin tingginya tingkat kematangan gonad.

Effendie (1997) mengatakan semakin tinggi tingkat perkembangan gonad, perbandingan antara bobot tubuh dan gonad semakin besar. Hal tersebut dapat dijadikan indikator bahwa pemijahan semakin dekat maka nilai indeks kematangan gonad mencapai maksimum dan akan berkurang setelah ikan memijah. Kenaikan indeks kematangan gonad erat kaitannya dengan pertumbuhan gonad dan peningkatan jumlah kuning telur, di mana saat indeks kematangan gonad I dan II gonad mengalami pertumbuhan bobot dan panjang juga dalam hal jumlah selnya, begitu juga pada indeks kematangan gonad IV yang mana pertumbuhannya cukup besar juga dipengaruhi dengan mulai banyaknya material penyusun sel telur sampai tahap pematangan, salah satu proses yang mempunyai peranan penting adalah vitelogenesis. 


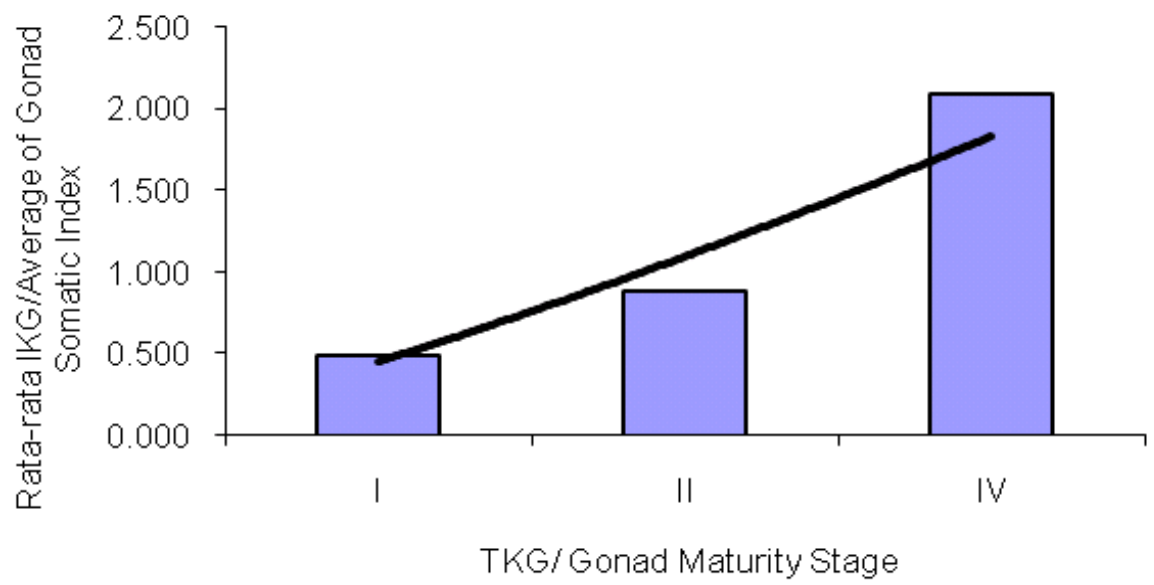

Gambar 4. Hubungan antara rata-rata indeks kematangan gonad dengan tingkat kematangan gonad dan ikan tuna mata besar di perairan Samudera Hindia, bulan Maret sampai Oktober 2008. Figure 4. Relationship between of gonad maturity stage and average of gonad somatic index of bigeye tuna in the Indian Ocean during the period of March until October 2008.

Hasil analisis menunjukan nilai rata-rata indeks kematangan gonad bervariasi tiap bulannya. Pada bulan Maret sampai Mei terjadi penurunan indeks kematangan gonad, dari 0,897 pada bulan Maret sampai 0,491 pada bulan Mei. Sementara itu pada bulan Oktober indeks kematangan gonad semakin meningkat yaitu 2,093 (Gambar 5). Hal ini berarti bahwa pada bulan Oktober diduga ikan tuna mata besar sudah siap memijah. Hasil penelitian Nootmorm (2004) mengatakan bahwa aktivitas spawning ikan tuna mata besar di timur Samudera Hindia, yaitu berlangsung dari bulan Desember sampai Januari dan bulan Juni. Sementara itu hasil penelitian Nishikawa et al. (1985) menunjukan bahwa pemijahan ikan tuna mata besar di Samudera Pasifik Timur terjadi antara bulan April sampai September di belahan bumi utara dan antara bulan Januari sampai Maret di belahan bumi selatan. Adanya perbedaan ini diduga karena penelitian ini tidak dilakukan selama satu tahun penuh, sehingga tidak mencakup puncak-puncak pemijahan dari ikan tuna mata besar, atau karena ikan tuna mata besar memijah sepanjang tahun, sehingga pada bulan Oktober diduga ikan tuna mata besar sudah mulai memijah.

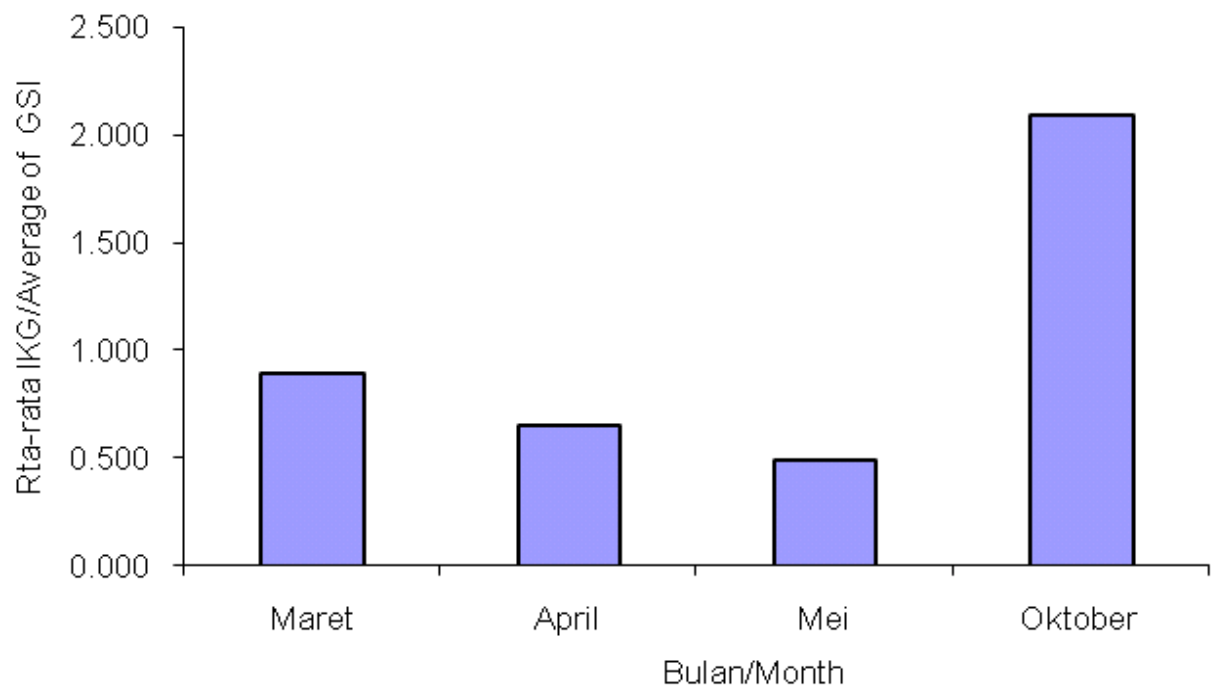

Gambar 5. Sebaran indeks kematangan gonad bulanan ikan tuna mata besar di perairan Samudera Hindia, bulan Maret sampai Oktober 2008.

Figure 5. Distribution of monthly gonado somatic index of bigeye tuna in Indian Ocean, March until October 2008. 


\section{Fekunditas}

Pengetahuan tentang fekunditas dari suatu jenis ikan merupakan faktor yang sangat penting untuk mengetahui siklus hidup ikan tersebut. Pendugaan fekunditas dari suatu jenis ikan sangat berguna untuk mengetahui kemampuan bertahan hidup anakan ikan dan evaluasi stok ikan. Fekunditas adalah jumlah telur ikan betina sebelum dikeluarkan pada waktu akan memijah. Hunter et al. (1992) mengatakan bahwa fekunditas total adalah jumlah telur yang terdapat di dalam ovari yang akan dikeluarkan pada waktu memijah. Fekunditas tahunan adalah jumlah telur yang dikeluarkan per tahun. Pada ikan yang memijah beberapa kali dalam satu tahun, fekunditas adalah rata-rata jumlah telur setiap kali pemijahan. Jumlah telur per satuan panjang atau bobot dinamakan fekunditas relatif.

Dari keseluruhan contoh gonad ikan tuna mata besar yang diamati hanya dua ekor yang memenuhi syarat untuk dihitung fekunditasnya. Ikan tersebut berukuran panjang cagak (FL) $141 \mathrm{~cm}$ dengan bobot
$54 \mathrm{~kg}$ dan panjang cagak $136 \mathrm{~cm}$ dengan bobot 47 $\mathrm{kg}$. Fekunditas dari masing-masing ikan 10.365.317 dan 8.163.715 butir. Menurut Nikaido et al. (1991) fekunditas tuna mata besar dapat meningkat secara dramatis dengan pertambahan panjang tubuh dengan perkiraan batch fekunditas tuna mata besar berkisar sekitar 1.000.000-5.000.000 butir telur setiap periode pemijahan dengan ukuran ikan berkisar dari 120-180 $\mathrm{cm}$. Kemudian Yuen (1955) mengatakan bahwa tuna mata besar di Pasifik Barat dengan ukuran 40-100 $\mathrm{cm}$ memiliki rata-rata batch fekunditas berkisar 2.668.000-6.300.000 butir. Sun et al. (2006) menambahkan batch fekunditas untuk tuna mata besar di Pasifik Barat 845.000-11.848.000 butir telur dengan ukuran ikan berkisar $100-180 \mathrm{~cm}$.

\section{Diameter Telur dan Pola Sebaran Telur}

Pada penelitian ini telah diamati 600 contoh telur. Dari hasil pengamatan diperoleh diameter telur ikan tuna mata besar bervariasi antara 99,50-830,44 $\mu \mathrm{m}$ (Gambar 6).

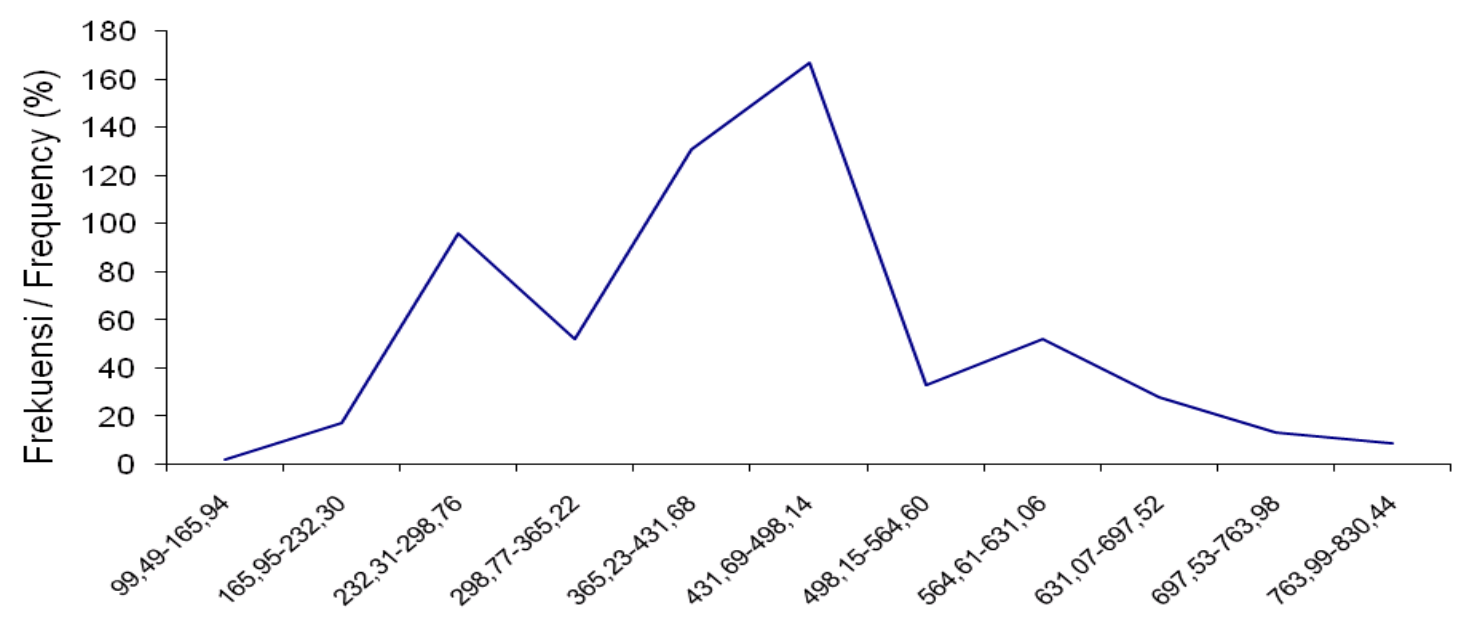

Diameter telur / Egg diameter $(\mu \mathrm{m})$

Gambar 6. Hubungan antara persentase jumlah telur dengan diameter tuna mata besar di Samudera Hindia pada gonad yang matang/mature (tingkat kematangan gonad IV) ( $\mathrm{n}=300$ butir).

Figure 6. Relationship between percentage of number of egg and egg diameter of bigeye tuna in Indian Ocean at the gonado somatic index IV ( $n=300$ eggs).

Dari gambar tersebut terlihat ada tiga modus penyebaran. Puncak pertama terjadi pada ukuran $232,31-298,76 \mu \mathrm{m}$ sebesar $16 \%$, puncak kedua terdapat pada ukuran 431,69-498,14 $\mu \mathrm{m}$ sebanyak $27,83 \%$, dan puncak ketiga terdapat pada selang ukuran 564,61-631,06 $\mu \mathrm{m}$ sebesar $8 \%$. Selanjutnya terlihat juga bahwa pola sebaran diameter telur memiliki lebih dari satu kelompok yang berbeda satu dengan kelompok lainnya tetapi memperlihatkan proses yang berkesinambungan. $\mathrm{Hal}$ ini mengindikasikan bahwa pola pemijahan ikan tuna mata besar berlangsung dalam waktu yang panjang atau telur yang dikeluarkan sebagian-sebagian (partial spawning) (Effendie, 2002). Kemudian berdasarkan atas pengamatan histologi gonad ikan tuna mata besar juga terlihat bahwa ukuran diameter oocyte sangat bervariasi dalam suatu gonad, hal ini menunjukan ikan tuna mata besar mempunyai pemijahan berganda (multiple spawner) atau pemijahan sepanjang tahun. Hal ini didasarkan atas 
perkembangan diameter telur menurut Murua \& Kraus (2003) bahwa tipe perkembangan oosit pada ikan tuna mata besar termasuk ke dalam tipe perkembangan asynchronous, yaitu oosit dari setiap tahap perkembangan dan berbagai ukuran diameter ada dalam telur dan tidak ditandai dengan populasi yang dominan. Ketika proses pematangan terjadi maka akan tampak adanya perbedaan ukuran diameter telur terutama telur tahap hidrasi dan pengumpulan kuning telur, pada spesies yang memiliki musim pemijahan relatif panjang atau berlanjut. Hal ini diperkuat oleh pernyataan Nishikawa et al. (1985); Miyabe (1994) yang mengatakan bahwa ikan tuna mata besar di Samudera Atlantik, Hindia, dan Pasifik memijah sepanjang tahun.

\section{KESIMPULAN}

1. Tingkat kematangan gonad ikan tuna mata besar betina yang ditangkap dari Samudera Hindia selatan Jawa selama penelitian mempunyai tingkat kematangan gonad I, II, dan IV.

2. Pemijahan ikan tuna mata besar diduga terjadi sepanjang tahun dengan pola pemijahan bersifat parsial.

3. Ikan tuna mata besar memiliki potensi pemijahan yang tinggi.

\section{PERSANTUNAN}

Tulisan ini merupakan kontribusi dari kegiatan hasil riset studi populasi genetik dengan menggunakan marker DNA dan biologi reproduktif ikan tuna Samudera Hindia, T. A. 2008, di Pusat Riset Perikanan Tangkap-Ancol, Jakarta. Dalam kesempatan ini penulis mengucapkan terima kasih kepada Ir. Retno Andamari, M.Sc. yang telah banyak membantu dalam preparasi dan analisis histologi. Terima kasih juga disampaikan kepada para observer pada Stasiun Monitoring Tuna Benoa, Pusat Riset Perikanan Tangkap yang telah membantu dalam pengambilan contoh gonad.

\section{DAFTAR PUSTAKA}

Collette, B. B. \& C. E. Nauen. 1983. FAO species catalogue. Vol. 2. Scombrids of the World. An annotated and illustrated catalogue of tunas, mackerels, bonitos, and related species known to date. FAO Fish. Synop. Rome. Food and Agriculture Organization. 125 (2).
Davis, T., J. Farley, M. Bravington, \& R. Andamari. 1996. Size at first maturity and recruitment into egg production of southern bluefin tuna. Final Report CSIRO Marine Research.

Direktorat Jenderal Perikanan Tangkap. 2005. Statistik Perikanan Tangkap Indonesia 2003. Direktorat Jenderal Perikanan Tangkap. Departemen Kelautan dan Perikanan. Jakarta.

Effendie, I. M. 1997. Biologi Perikanan. Yayasan Dewi Sri.

Effendie, I. M. 2002. Biologi Perikanan. Yayasan Pustaka Nusantara.

Figueiredo, M. B, A. G. Santos, P. Travassos, C. M. Torres-Silva, F. H. V. Hazin, R. Coeli, B. R. Magalhães. 2008. Oocyte organization and ovary maturation of the bigeye tuna (Thunnus obesus) in the west tropical Atlantic Ocean. Collect. Vol. Sci. Pap. ICCAT. 62 (2): 579-585.

Hunter, J. R., B. J. Macewicz, N. Chyanhuilo, \& C. A. Kimbrill. 1992. Fecundity, spawning, and maturity of female dover sole, Microstumus pacificus with and evaluation of assumption and precisions. Fishery Bulletin. 90: 101-128.

Itano, D. G. 2000. The Reproductive Biology of Yellowfin Tuna (Thunnus albacares) in Hawaiian Water and the Western Tropical Pacific Ocean: Project Summary. PFRP, JIMAR, UH, HI. JIMAR Contribution. 00-328. 69 pp.

Lowe, R. T. 1839. A supplement to a synopsis of the fishes of Madeira. Proc. Zool. Sic. Lond. 76-92.

Miyabe, N. 1994. A review of the biology and fisheries for bigeye tuna, Thunnus obesus, in the Pacific Ocean. In Shomura R. S., Majkowski J., Langi S., editors. Interactions of Pacific tuna fisheries. Proceedings of the First FAO Expert Consultation on Interactions of Pacific Tuna Fisheries; 1991 Dec 3-11; Noumea. New Caledonia. Rome: FAO. 2. $207 \mathrm{pp}$.

Murua, H. \& G. Kraus. 2003. Procedur to Estimate Fecundity of Marine Species in Relation to their Reproductive Strategy. J. Northw. Atl. Fish. Sci. 33: 23-32. 
Nikaido, H., N. Miyabe, \& S. Ueyanagi. 1991. Spawning time and frequency of bigeye tuna, Thunnus obesus. Bull. Nat. Res. Inst. Far. Seas. Fish. 28: 47-73.

Nishikawa, Y., M. Honma, S. Ueyanagi, \& S. Kikawa. 1985. Average distribution of larvae of oceanic species of Scombroid fishes, 1956-1981. Ser. Far. Seas. Fish. Res. Lab. (12): 99 pp.

Nootmorn, P. 2004. Reproductive Biology of Bigeye Tuna in the Eastern Indian Ocean. Document IOTC-2004-WPTT-05. Presented at the Working Party on Tropical Tunas. Victoria. Seychelles. July 13 th-20 2004.

Proctor, C. H., G. S. Merta, M. F. A. Sondita, R. I. Wahyu, T. L. Davis, J. S. Gunn, \& R. Andamari. 2003. A review of Indonesia's Indian Ocean Tuna Fisheries. ACIAR Project FISH/2001/079 Country Status Report.106 pp.

Pusat Riset Perikanan Tangkap. 2002. Analisis pengelolaan perikanan tuna di Samudera Hindia dan perikanan perairan umum di Sumatera Barat. Laporan Teknis Bagian Proyek Riset Perikanan
Tangkap Tahun Anggaran 2002. Jakarta. Pusat Riset Perikanan Tangkap. Badan Riset Kelautan dan Perikanan. Departemen Kelautan dan Perikanan.

Schaefer, M. B. \& C. O. Orange. 1956. Studies on sexual development and spawning of yellowfin tuna (Thunus albocares) and skipjack (Katsuwonus pelamisf in three areas of the Eastern Pacific Ocean, by examination of gonads (in Engl, and Span). Intercom. Trop. Tuna Comm. Bull. 1: 263349.

Sun, C. L, S. L. Chu, \& S. Z. Yeh. 2006. The reproductive biology of female bieye tuna (Thunnus obesus) in the Western Pacific. Scientific Committee Second Regular Session. Manila, Philippines. 22 pp.

Uktolseja, J. C. B. 1997. Pengaruh kedalaman mata pancing rawai tuna terhadap hasil tangkapan ikan tuna. Jurnal Penelitian Perikanan Laut. 49.

Yuen, H. S. H. 1955. Maturity and fecundity of bigeye tuna in the Pacific. U.S. Fish Wildl. Serv. Spec.Sci.Re.Fish. 150: 30 pp. 